\title{
Fifty years of scientific and technical information policy in France (1955-2005)
}

\author{
Serge CACALY
}

Université de Marne la Vallée, France

Yves-François LE COADIC

CNAM, Paris, France

Correspondance to: Serge CACALY, Laboratoire Ingénierie Des Systèmes D'informations Stratégiques et Décisionnelles (ISIS) - Université de Marne la Vallée - Cité Descartes - 5, boulevard Descartes Champs sur Marne 77454 Marne la Vallée cedex 2 - France. E-mail : cacaly@univ-mlv.fr

\begin{abstract}
Over the last fifty years, French public authorities have played a major role in developing a policy for scientific and technical information (STI) in France. Four distinct periods can be identified. During the first from 1955 to 1973, policy was dominated by de Gaulle's concern to combat American hegemony and, since that time, STI policy has always been considered a part of French global politics. The second period from 1973 to 1982 saw the construction of the national STI infrastructure which was followed by a focus on content and database coordination up to 1993. Since that date, France's policy has been marked by the deregulation of telecommunications and the privatization of public services. The question addressed in this paper concerns the current role of public authorities in preparing French society for active participation in the knowledge society.
\end{abstract}

Keywords: Information policy; Scientific and technical information; France; History of information science 


\section{Introduction}

The knowledge society is a catch-all term which we will use in this paper to capture some of the major choices shaping policy for scientific and technical information (STI). In a context of wide ranging public debate, oppositions are being forged which are shaping the emergence of the knowledge society. Obviously, knowledge doesn't take on the same meaning for those that use it to defend cultural diversification against cultural domination, nor for those who demand the respect of local as opposed to global identities. France has a long tradition of debating these types of subjects which goes back to Colbert ${ }^{i}$. In our historical study of STI policy over the last 50 years our goal is to explore the relationships between this policy and the wider political issues of the knowledge society debate. But of course the relationship is not unidirectional. For budgetary and other reasons linked to its national political context, France's capacity to contribute positively to the knowledge society debate is waning. It appears less and less able to formulate an independent information policy which, as we will show, is absolutely necessary if a country wants to influence the outcome of the knowledge society debate.

In any case, Charles de Gaulle was definitely of this opinion ${ }^{\text {ii }}$. The Gaullist years were when STI policy was formed in France, but we've taken 1955 as a starting point for this study because that was when the American Department of Defence automated its documentation. The idea of computer supporting efforts to improve access to scientific and technical information was making headway, but after 1955 this goal was clearly seen as being a policy priority.

\section{1955 -1973: The recognition}

In the middle of the 50s, some pioneers, often on the fringe of their communities, were convinced that computers would become a major device for accessing and disseminating information. Among them were J.C. Gardin, R. Ginouvès and J.E. Dubois who actively launch the construction of databases in their respective fields, archaeology and chemistry. Information science in France grew out of their efforts which were solidly anchored in scientific research aimed at developing robust methods and procedures for information representation and communication.

1959 marks the beginning of active involvement of public authorities in IST with the creation of associations and commissions placed under the authority of the General Delegation of Scientific and Technical Research (DGRST), a precursor of what was later to become the French Research Ministry. The DGRST published a 


\section{Fifty years of scientific and technical information policy in France (1955-2005)}

report on document processing in 1962 which was of major importance for launching the database industry and then, one year later, published the first major policy document aimed at implementing a national STI program in France [1]. It stressed the need for an independent national communication network and a coherent, global approach to STI decision-making. The political context clearly justified this policy orientation: France had asked the American administration to supply it with a computer for its atomic bomb research, but the request had been refused. In 1963, de Gaulle reacted by launching the Plan Calcul [2] and declaring publicly that it was in France's national interest to invest heavily in building an independent research system.

The political visibility of STI questions was assured for some years after 1963 in a context dominated by the Gaullist concern for an independent research system focused on France's national priorities. In 1971, the "Commissariat Général du Plan"iii played up once again on this theme, producing a document underlining the growing risk of depending upon American sources of scientific and technical information. At this time, the mostly "anti-american" drive of French contribution to international STI programs (e.g. DIRR, INIS, ARIS, etc.) was evident. The same case was made again as it had been 8 years earlier: a coherent, global and independent information policy was urgently required given, this time, the opening of two American international telecommunication networks TYMNET and TELENET and the opening of online access to major American bibliographic banks (ORBIT (SDC), DIALOG, BRS, MEDLINE (NLM). Obviously, no customs officer could stop the information flow; the concept of a "data war" was proposed to characterize what was perceived as a new and highly dangerous situation for French research [6]. At an international level as well, the Organization for Economic Cooperation and Development (OECD) published a report in 1971 entitled "Information in an evolving society" [4] which established a direct relationship between STI and economic growth. Finally, UNESCO announced the launch of an ambitious information program called UNISIST (study on the implementation of a worldwide system for scientific information) arguing the undesirable effects of STI monopolies: "The improvement of document management systems include a real danger that the intellectual, technical and financial means needed to produce them will become concentrated in the hands of a small number [...]. Monopolies can arise in scientific and technical information areas and lead to the subordination of the majority to the minority but they can reside within and between nations as well." [5]

The time had come to build the National STI Policy that 10 years of active, behind-the-scenes analysis, proposals and initiatives had prepared. 


\section{1973-1982: The construction}

The growing recognition of STI's role in national development was fully acknowledged with the creation of the Bureau National de l'Information Scientifique et Technique (BNIST) on February 7, 1973. This Bureau was set up to enact the recommendations of the "Commissariat au Plan". It was linked to the Ministry of Industry and Trade, but the word "National" in its title proved the Government's intention of setting up a coordinating body. The BNIST task assignments were:

to pilot STI national policy;

to gain political support by winning government-wide approval for its policy proposals;

to coordinate the implementation of these proposals in the different ministries and other concerned institutions;

Despite a small budget (1,2 $\mathrm{M} €$ budget in 1974 and $2 \mathrm{M} €$ in 1978), the BNIST was able to efficiently overcome the weakness of the French STI system by implementing 4 policies:

a national database policy specifically supported chemistry (DARC system ${ }^{\text {iv }}$ ), physics, medicine, textile;

a national policy of normalizing industrial and scientific vocabularies was launched respecting international standards;

a wide reaching program of information science research was initiated;

and, finally, efforts aimed at producing document retrieval software and training programs were supported (for example, the MISTRAL program run by the French champion in the computer industry, Bull)

The BNIST had valuable allies during this crucial period in the Direction Générale des Télécommunications (DGT which was to become France-Télécom) and in the Direction des Recherches et Moyens d'Essais (DRME, the defence research department). For example, in the DGT, a huge investment in the telematics network TELETEL (and the terminal MINITEL) was engaged. And the DRME created a "Bureau de l'Information Scientifique" whose goal was to develop databases, surveys and to organize international conferences in order to strengthen and consolidate the empirical, intellectual and theoretical foundations of the French information infrastructure. The first French national conference on "information and documentation" was organized on December 1974 under the auspices of the BNIST and the DRME by the Association des Documentalistes et Bibliothécaires Spécialisés (ADBS) and the Association Nationale de la Recherche Technique (ANRT). This national event (named "IDT" in 1981 and since 2003 "i-expo") showed the support given by French professional associations to the public information policies being developed at that time [7]

During the 1970s, three reports were produced which laid out the foundations for a National STI policy. The first report concerned the database industry and derived from a growing Government concern to implement an "independent scientific and technical documentation network exerting a worldwide influence". The report was 


\section{Fifty years of scientific and technical information policy in France (1955-2005)}

published in 1979 and once again drew attention to the unacceptable consequences of an American information monopoly [8]. Explicitly equating information and power, the report underlined the risks of seeing France become economically, scientifically and culturally dependent should it loose control over its own STI policy and its right of access to worldwide information resources. Urgent measures were formulated which were aimed at building and maintaining a national bibliographic system through a central host service, at improving assistance for end users and at creating a wide variety of new information products and services. Four main ideas drove these measures: national independence, international cooperation, France's role in the world and a high level coordinated and global information strategy. For the first time, this report clearly stated that STI policy should be considered as an essential part of French national policy in general. The argument took hole: the BNIST was replaced by a more politically visible institutional structure called "Mission Interministérielle de l'Information Scientifique et Technique" (MIDIST). The conception of the MIDIST was similar to that of the American COSATI Both were to play the role of inter-ministerial bodies in charge of defining STI national policies, coordinating the action of ministries and concerned organizations and helping to set up the infrastructure needed by STI development. From 1980 on, MIDIST's budget was approximately $6 \mathrm{M} €$ a year, three times bigger than the BNIST budget. However, its objectives remained essentially the same. In order to improve France's competitive position, the MIDIST sought to encourage the fabrication of high quality information products [10] and avoid replication of what was done elsewhere. Databases like DARC were financially supported because they offered original, high value-added products and services. But at the same time, MIDIST set up a variety of Agencies in order to achieve specific objectives: Agence de l'informatique (Computer Agency), Direction des industries électroniques et informatiques (ICT Department), Agence universitaire de l'information scientifique et technique (STI academic agency).

The second report was produced at the request of the French President, Valéry Giscard d'Estaing, in an attempt to draw out the implications of computerization for French society. The Nora-Minc report was published in June 1978 and became a "best-seller" showing an unexpected interest of the general public for issues linking access to information, technological development and economic and social activity [11]. The success of the report greatly facilitated the adoption of the first policy recommendations. Finally, a third report was published in June 1979 which was less concerned with scientific and technical information, however, it reproduced the same type of argument with respect to the need for carefully managing economic and social information [12]. For the authors of the report, industrial development requires open access to economic and social information, not only for adjusting market decisions but also as a means of enriching the social dialogue thereby preparing collective action.

The new STI framework was completed with the creation of the National host Questel in 1979 by the Télésystèmes Company, a subsidiary of France-Telecom. MIDIST sought to achieve a strategic and political 


\section{S. CACALY AND Y.F. LE COADIC}

objective in sponsoring this initiative:

strategically, the fact of accessing information through American hosts such as ORBIT (SDC), DIALOG, BRS, MEDLINE (NLM), displayed France's research, economic and industrial options to its American competitors. Offering access to world information through Questel would help France avoid the dangers of providing competitive intelligence to the Americans. Americans would no longer be in a position to systematically monitor the information requests and access strategies of the French business and scientific communities.

Politically, Questel could be used as a show-window for France's high quality, value-added information products and services, providing assistance to France's database industry for both marketing and disseminating them.

QUESTEL started with 12 French bibliographic databases as well as the Chemical Abstract Service (CAS). This American giant of chemical information was offered through the French host because of a cooperation agreement between CAS and the Centre National de l'Information Chimique (CNIC), which institutional sponsored and supported the DARC system. This agreement designed the CNIC as a CAS partner with rights for distributing CAS products, setting up a service for bibliographic research and providing user training.

\section{1982-1993 : The coordination}

During the 1970's a parallel was drawn between information and the energy crisis that lead western countries to an economic crisis after 1973. Information was presented metaphorically as a new form of energy, just as important as oil in explaining a country's competitive position. And like oil, it had to be located, dug out, refined, transported and commercialized. Information, in other words, was increasingly being perceived as an industry requiring investments to build an appropriate infrastructure. In 1981, the GFFI (French Information Industry Association) captured this new awareness in a report calling for the need to turn information into a major sector of economic development [13]. France, it was argued, needs to build an information industry in order to support its strategic information needs: information is as crucial as oil for national independence.

From the 1980's on, public authorities largely committed themselves to this idea. All the French ministries and large public institutions created an information department. Trade and other civil society associations (librarians, database producers, editors, information professionals, etc.) became increasingly involved in policy definition and implementation. In July 1982, the Parliament voted a law which required scientists, as public servants, to communicate their results and popularize their use. A few months later, the CNRS (National Centre for Scientific Research) created a new Direction de l'Information Scientifique et Technique (STI department). However, despite this activity in the STI sector, a new policy direction was taking hold. The MIDIST was increasingly 


\section{Fifty years of scientific and technical information policy in France (1955-2005)}

concerned with a new concept, that of supporting and rationalizing the offer of specialized, professional information. One example was the decision taken in 1983 to create JURIDIAL, a company whose task was to provide a centralized access to legal databases, thereby avoiding redundant and often competing public funding of database producers in that sector [14].

However, even more important for the future of the STI concept in France was the change in Government that took place in 1981. When François Mitterrand was elected President of the Republic, MIDIST policy changed from being focussed on STI to one much more open, not only to the concept of specialized, professional information as we saw, but even more importantly, to the concept of scientific culture. The MIDIST turned its attention to supporting museums, popularizing science and publishing (JURIDIAL). After having long time been the prerogative of an inter-ministerial body, the centre of STI public policy making moved out of MIDIST into the Ministry of National Education. A new Department was created: the DBMIST, Direction des bibliothèques, des musées et de l'information scientifique et technique (STI, Libraries and Museums department) headed by D. Varloot. The task assignment of the DBMIST was to manage academic libraries and national education museums, formulate and implement a global STI policy for the Education Ministry and train teachers, librarians and professors.

To a large extent, the DBMIST pursued and developed the goals which had been defined in the 1970's and implemented first by the BNIST and then by the MIDIST until it changed directions and focused more on scientific culture after 1981 [16]. However, under the DBMIST, STI policy lost its inter-ministerial status: it was no longer a national policy but one of the Education Ministry even though the Education sector was by far the largest STI producer and user in France. That said, DBMIST initiatives and policies largely shaped and conditions the STI French scene [17]. A list of its main achievements follow:

National catalogue of publications $(\mathrm{CCN})$

Scientific and technical acquisition centers (CADIST)

Supply of primary documents to academic libraries (FOUDRE)

Support to the creation and development of many data banks and thematic networks

Help in the creation of the first scientific image databanks

Academic and national server for scientific and technical information (SUNIST)

Use of data banks in academic libraries

Online training for librarians and teachers

Regional units for training and promotion of STI (URFIST)

Program for academic research in information science (PARUSI) [18]

Renovation of scientific museums (Museum d'Histoire Naturelle de Paris) 


\section{S. CACALY AND Y.F. LE COADIC}

Program for academic research in museology (REMUS)

In the second half of the 1980s and early 1990s, in spite of protest [19] [20], most STI organizations were dismantled starting with the MIDIST in 1986 and then followed two years later by the DBMIST. In 1988, the CNRS merged its two documentation centres, the Centre de Documentation Scientifique et Technique (CDST) and the Centre de Documentation Sciences Humaines et Sociales (CDSH), to create in Lorraine at Nancy the Institut de l'information scientifique et technique (INIST). The stated goal was to open up perspectives of high qualifying jobs in leading edge technologies to regions suffering economic hardship from the loss of traditional industries (textiles, mines, steel). No effort was made to justify the decision scientifically or in terms of a national STI policy. The justification laid elsewhere: the idea of an information industry for Europe was making increasing headway; STI had lost its strategic visibility in France and was increasingly being considered as an area for private, industrial initiative; and, in the last analysis, the Lorraine needed the promise of new high tech industries to replace its traditional steel, mining and textile industries.

A general feeling was emerging that France could not compete on its own with the United States. Between 1982 and 1987, the budgets of American federal agencies went from 9.1 billion dollars to 16.1 billion dollars for computerization. Half of the agencies were actively using electronic mail. At the European level, the Commission had implemented the IMPACT programme which was a major action plan for the development of information services and products designed to support the creation of an information industry in Europe. STI was moving out of the national picture into a more European framework as we will show in discussing the various deregulation policies implemented between 1993 and 2005.

\section{1993-2005 : The deregulation}

In order to conclude this rapid survey of 50 years of STI policy in France, we will look rapidly at what has been taking place over the last 10 years, not so much in order to draw conclusions about the impact of globalization on French STI policies but, more simply, to provide the reader with an idea of the types of decisions which are being taken. These decisions show a clear rupture with past policy.

In 1993, the vice-president of the United-States, Al Gore, launched the concept of "information highways". The use of this metaphor allowed him to suggest that just as improved transport had been a motor of economic development in the $20^{\text {th }}$ Century, efficient and effective transport of kilo-bits of information to people that require it will be one of the driving forces of economic and social development in the $21^{\text {st }}$ Century. The Internet is a 


\section{Fifty years of scientific and technical information policy in France (1955-2005)}

prototype of an Information highway; its speed, flexibility, decentralization and information transmission capabilities being its main assets. Al Gore's idea took hold: the United States launched a program valued at more than $200 \mathrm{M}$ dollars to foster the development of new information and communication technologies.

In France, a public policy reaction to the American initiative only took place in 1997. Before that time, the private sector was expected to react with the help of trade associations whose role remained strong. Reports that pointed to the need for a specific French approach to Internet and the idea of Information Highways received little attention [22]. More was given to business opportunities arising out of new forms of competitive practices. For example, a report on "Business Intelligence and entrepreneurial strategy" was published in 1994 which highlighted the need for economic intelligence in today's global market [21]. Business intelligence means devising a plan of coordinated actions in all areas of the modern enterprise - research, management, distribution, etc. - in order to have a framework for identifying, collecting, processing and analyzing relevant information. The authors suggested that a public policy could contribute to this goal by setting out a long-term strategy for national economic, scientific and social development, thereby creating a positive climate for business investment and initiative. But until 1997 the philosophy was very liberal, the role of public intervention being to create the conditions for private initiative. For example, the telecommunications sector was deregulated in 1996 when new relationships were installed between telephone, cable television, radio-diffusion and wireless transmission operators.

When the Left took over the reigns of Government in 1997, the Prime Minister Lionel Jospin announced his intention to prepare France for entry into the information society and launched a program called PAGSI [23]. PAGSI started in 1998 and had six orientations: education, culture, administration modernization, electronic commerce, research and innovation, security and control over the use of technologies. Some projects have been carried out: Educasource (directory of multisupport resources organized per field), Educnet (use of information technologies in educational systems), the implementation of a web server in each ministry, electronic administration forms available on the Internet...

However, STI was only a minor part of this program despite the fact that conditions of accessing, processing and analyzing scientific and technical information have been greatly affected by the growing use of Internet. Despite the fact that a great deal of academic research is being carried out on these questions (see for example the Action Spécifique programs of the STIC Department of the CNRS), few policy initiatives are being taken in France to support the emergence of new, emerging forms of collective, computer-mediated STI activities. Policy making on these issues is now firmly located at the European Commission in discussions over the content and development of its R\&D Framework Research Programs. The French PAGSI program has produced comparatively few results: a university documentation system (SUDOC) containing the individual catalogues and 
electronic documents of French universities; services provided to University administrations for digitalizing university documents; remote teaching projects and the creation of library consortiums.

\section{Conclusion}

Today, in France, the viability of a STI policy can be raised. Our article has shown that the scope of such a policy seems much less today than what it was in the past, when STI was seen as a factor of national independence. Furthermore, the civil society seems to be evolving today towards less state power and more private initiatives as witnessed by privatizations and deregulation. Finally, the growing use of information technologies for accessing, processing and analyzing information wherever it is found in the world would seem to play against the efficiency of a national information policy. That said, things change quickly and political awareness remains high of the following inescapable causal relationship underlying an information and knowledge-based economy: namely that there is no innovation without research, no research without STI and no social and economic development without STI.

\section{References}

[1] Délégation à la recherche scientifique et technique (DGRST). Rapport à Monsieur le Ministre d'Etat chargé de la recherche scientifique et des questions atomiques et spatiales (La Documentation Française, Paris, 1963).

[2] Ministère du Développement Industriel, L'informatique en France : le Plan Calcul (La Documentation Française, Paris, 1968).

[3] Commissariat Général au Plan, Rapport du groupe de travail GR5, VI ${ }^{\text {ème }}$ Plan 1971-1975 : la recherche scientifique et technique (Commissariat Général au Plan, Paris, 1971).

[4] OECD, The Information in an evolving society (OECD, Paris, 1971).

[5] UNESCO, UNISIST. Study on the implementation of a worldwide system on scientific information (UNESCO, Paris, 1971). 


\section{Fifty years of scientific and technical information policy in France (1955-2005)}

[6] A. Lefébure and M. Ronai, La guerre des données, Le Monde Diplomatique 11 (1979).

[7] J. Michel, La politique de la France en matière de réseau d'information. In : Premier Congrès National d'information et de documentation (ADBS, Paris, 1974).

[8] P. Aigrain and A. Dejou, Rapport du président du groupe de travail sur l'information scientifique et technique, (Unpublished report, DGRST, Paris,1979).

[9] BNIST, Rapport annuel d'activité (Ministère de l'Industrie et de la Recherche, Paris, 1978).

[10] J. Michel and M.F. Morin, Action du BNIST : Politiques et systèmes d'information scientifique, La revue de l'AUPELF 16 (1978).

[11] S. Nora and A. Minc, L’informatisation de la société (La Documentation Française, Paris, 1979).

[12] R. Lenoir and B. Prot, L’information économique et sociale, Rapport au Président de la République (La Documentation Française, Paris, 1979).

[13] GFPBBD, Les bases et banques de données, pétrole gris, une chance pour la France (GFPBBD, Paris, 1981).

[14] P. Leclercq, Rapport de mission sur l'information juridique, rapport au Premier Ministre (Unpublished rapport, Paris,1984).

[15] A. Mattelart and Y. Stourdzé, Technologie, culture et communication, Rapport au Ministre de la Recherche et de l'Industrie (La Documentation Française, Paris, 1982).

[16] S. Cacaly, Politique française des banques de données en matière de sciences humaines et sociales. In : T. F. Moberg (ed.) Databases in the humanities and social sciences 1985, (Paradigm Press, Osprey, USA, 1986).

[17] Y. F. Le Coadic and S. Chambaud, Policies and politics in the scientific and technical information sector in France, Journal of Information Science 19 (6) (1993).

[18]. S. Chambaud and Y. F. Le Coadic, Basic research in information science in France, Information Processing \& Management 23 (5) (1987). 
[19] Y. F. Le Coadic, Une politique scientifique pour l'information, Documentaliste-Sciences de l'information 26 (2) (1989).

[20] S. Cacaly, Les pouvoirs publics dans l'histoire des banques de données, Documentaliste-Sciences de l'information, 27 (3) (1990) 127-131.

[21] H. Martre, Intelligence économique et stratégies des entreprises, Rapport du groupe de travail du Commissariat au Plan (La Documentation Française, Paris, 1994).

[22] G. Théry, Les autoroutes de l'information (La Documentation Française, Paris, 1994).

[23] Service d'information du Gouvernement, Préparer l'entrée de la France dans la société de l'information. Programme d'action gouvernemental (Premier Ministre, Paris, 1998).

\footnotetext{
i COLBERT Jean Baptiste (1619-1683) - Powerful contrôleur général (roughly, a Minister of Finance) under King Louis XIV of France. Despite the Sun King's extravagance, Colbert managed to keep French state finances reasonably solvent. He believed in Mercantilist doctrine that the expansion of commerce (and the maintenance of a favourable balance of trade) was the key to State wealth. His policies -- what became known as Colbertisme -- were all geared in this direction. http://cepa.newschool.edu/het/profiles/colbert.htm

${ }^{\text {ii }}$ De GAULLE Charles (1890-1970) - The main doctrinal component of Gaullism is a desire for France's independence from foreign power, but there are also social and economic components in some forms of the philosophy. http://en.wikipedia.org/wiki/Gaullist

iii Commissariat Général du Plan - official body created in 1946 by De Gaulle for national planning and prospective. It has been suppressed in 2005.

iv DARC = Documentation and Automated Research of Correlations : an online chemical substructure search service. Preceded five years before by Wiswesser Line Notation, a computer-stored representation of molecular structures.
} 